


\title{
Sleeping with the Enemy: \\ The Perils of Having the Government On(the)board
}

\author{
Santiago Barraza ${ }^{a}$, Martín A. Rossi ${ }^{\text {b }}$, and Christian A. Ruzzier ${ }^{c}$
}

${ }^{\text {a }}$ ESCP Business School, Corso Unione Sovietica, 218 bis, 10134 Turin, TO, Italy, Tel.: (+39 011) 670 5743, E-mail: sbarraza@escp.eu.

${ }^{\mathrm{b}}$ Departamento de Economía, Universidad de San Andrés, Vito Dumas 284 (B1644BID) Victoria, Buenos Aires, Argentina, Tel.: (+ 54 11) 70780400 int 5700, Fax: (+54 11) 7078 4000, E-mail: mrossi@udesa.edu.ar.

${ }^{c}$ Departamento de Economía, Universidad de San Andrés, Vito Dumas 284 (B1644BID) Victoria, Buenos Aires, Argentina, Tel.: (+ 54 11) 70780400 int 4570, Fax: (+54 11) 7078 4000, E-mail: cruzzier@udesa.edu.ar. [Corresponding author]

\begin{abstract}
We study the causal effect of unsought political connections on firm value. To address concerns of potential endogeneity and sample-selection bias we exploit the nationalization of Argentina's pension system, a unique natural experiment yielding exogenous variation in new political connections. We find unsought political connections to have a large negative effect on the value of newly connected firms. Yet this result only materializes when, in addition to becoming a shareholder, the government also obtains the right to appoint directors. Decreased stock liquidity or higher stock volatility do not explain this result, suggesting a channel that decreases expected cash flows to shareholders.
\end{abstract}

Keywords: Political connections, corporate governance, grabbing hand, firm value, government ownership.

JEL Codes: G32, G34, H11, H13, O16.

December 2021 


\section{Introduction}

Firm ties to governments and politicians (often called political connections) are widespread all over the world (Faccio, 2006). An obvious explanation for this fact is that firms must be deriving net benefits from being connected, and evidence of a positive relationship between political connections (either through explicit ties with politicians or through campaign contributions) and firm value indeed abounds (see, e.g., Claessens, Feijen, and Laeven, 2008; Cooper, Gulen, and Ovtchinnikov, 2010; Faccio, 2006; Faccio and Parsley, 2009; Ferguson and Voth, 2008; Fisman, 2001; Goldman, Rocholl, and So, 2009; Jayachandran, 2006; Johnson and Mitton, 2003; Palanský, 2021; Ramalho, 2007; and Roberts, 1990).

Political connections are presumably endogenous-e.g., if connections affect value, firms have incentives to seek those connections or try to avoid them — but even when endogeneity concerns are properly addressed, studies in this literature typically measure existing political connections (like personal ties to a senator or previous campaign contributions to a political party), and analyze shocks to the usefulness of these connections (like the sudden death of the senator or an unexpected electoral defeat of the party) to infer their value to firms. But if firms actively seek or try to avoid political connections (as recently shown by Akey and Lewellen, 2017; Hassan et al., 2019; and Kung and Ma, 2018), the connections that are observed and measured should be, on average, those that create most value to firms, and therefore existing studies could suffer from a potential problem of sample selection. In this light, the usual finding of a positive impact of political connections on firm value turns out to be not that surprising: preexisting connections were probably sought by firms, and likely because they added value to the firm; when these connections are (say) cut for exogenous reasons, the market adjusts firm value down accordingly. Without controlling for sample selection, the 
conclusions on the value of political connections that have been drawn by previous research could be biased.

The contribution of this article is not just to merely warn of this problem, but to address it by exploiting a unique natural experiment that yields exogenous variation in new political connections (i.e., connections that were not sought or desired) at the firm level to provide a novel view of their effect on firm value, arguably free from endogeneity (as in several existing studies) and sampleselection concerns (as in no paper that we are aware of). Our natural experiment consists of the nationalization of Argentina's pension system in 2008. A law passed towards the end of 1993 in the country had established a mixed pension system in which workers' contributions accumulated in individual capitalization accounts, managed by private fund managers, called Administradoras de Fondos de Jubilaciones y Pensiones (AFJPs). The law allowed the AFJPs to invest their funds in, among other securities, shares in domestic (private, publicly-listed) firms. In October 2008, an unexpected announcement made by President Cristina Fernández de Kirchner started the rapid legislative process that would lead to the nationalization of Argentina's private pension funds only a month later. The new law transferred all of the AFJPs' assets (including shares in domestic firms) to a fund run by the government, which thereby became an unexpected shareholder in those firms for reasons that were unrelated to their market value. What were small ownership stakes when dispersed among several AFJPs became larger shareholdings when concentrated in the hands of a single owner, the Argentine government, and in some cases the shareholding granted the government the right to appoint one or more directors to the boards of those firms-giving us also a plausible source of exogenous variation in board composition across different firms.

Consistent with prior literature (e.g., Faccio, 2006; Frye and Iwasaki, 2011; Khwaja and Mian, 2005; Wu, 2011), we interpret a positive government shareholding and the right to have government- 
appointed directors on the board as measures of a firm's political connections, and use the nationalization of the pension system as a source of exogenous variation in these connections. Since some firms just saw the government come on board as a shareholder, while a fraction of these firms learned that the government could also appoint directors to their boards, we have in fact two different, nested treatments that we exploit in our empirical exercise.

We find that political connections have a large negative effect on the market value of connected firms, but only when, in addition to becoming a shareholder, the government has the right to appoint directors to the board: depending on the specification, stock prices are on average $23-40 \%$ lower (compared to a baseline period) after the nationalization in these firms. These results are consistent with the grabbing-hand perspective of Shleifer and Vishny (1994, 1998) — not only because of the negative effect of connections on firm value, but also because political connections are detrimental only when they grant the government a concrete ability to interfere with firm activities (e.g., to drive firms towards political rather than economic goals, or to engage in rent seeking).

We also show that the negative effect on stock prices is not driven by changes in liquidity (i.e., government fund managers trading differently from the AFJPs after the nationalization). Absent a liquidity effect, changes in stock prices can be due to reductions in expected cash flows to equity, an increase in the perceived riskiness of these cash flows, or both. Since increased riskiness should result in increased market volatility of a firm's stock return, we focus on this measure in the analysis, and find that neither treatment had a significant effect on volatility, leaving changes in expected cash flows as a likely driver of our results. Though suggestive, this evidence is admittedly indirect and should be interpreted with caution, as we do not have data on cash flows to address the matter more directly. 
Our paper contributes to the growing economic literature on politicians and firms, especially to the body of work assessing the net effect of political connections on firm value, by providing evidence of their impact free from sample selection. Studies reporting a negative effect of connections on firm value or performance are relatively few, and concentrated in China (e.g., Fan, Wong and Zhang, 2007; and Shi, Xu and Zhang, 2018, contain event studies focusing on cumulative abnormal returns; Harrison et al., 2019, analyze return on assets and total factor productivity using panel data; and Chen et al., 2017, report effects on Tobin's Q with cross-sectional data). These negative results can be interpreted in light of our sample selection argument. To the extent that preexisting political connections (like a government bureaucrat acting as CEO, or a National People's Congress official serving as director) were not necessarily sought (or could not be avoided) by firms in these cases, negative effects on firm value are more likely to arise in the Chinese context than in the typical study.

Our finding that a seat on the board is an important channel for government influence speaks to the larger literature on government ownership (including work on privatization, and publicly listed firms in China with partial government ownership). ${ }^{1}$ We also add to the literature on boards of directors and firm value (see the surveys by Adams, Hermalin, and Weisbach, 2010; Hermalin and Weisbach, 2003; and Johnson, Daily, and Ellstrand, 1996) — especially the part of that literature focusing on directors' characteristics ${ }^{2}$ - by considering directors with the distinguishing characteristic of being appointed by the government, and also by proposing a plausible identification

\footnotetext{
${ }^{1}$ See, e.g., Bortolotti and Faccio (2009); Fan, Wong and Zhang (2007); Shleifer (1998); Tian and Estrin (2008); and Wei, Xie and Zhang (2005).

${ }^{2}$ See, e.g., Adams and Ferreira (2009) for the case of female directors; Goldman, Rocholl, and So (2009) for directors with political backgrounds; Güner, Malmendier, and Tate (2008) for directors with banking experience; and Masulis et al. (2012) for directors with previous industry experience.
} 
strategy to deal with the endogeneity concerns that plague this literature (as pointed out, for instance, by Hermalin and Weisbach, 2003).

Closest to our work are papers studying the value effects of politically-connected board members. Boubakri, Cosset and Saffar (2008), Ferguson and Voth (2008), and Goldman, Rocholl and So (2009) report positive effects of politically-connected directors, whereas Cheung, Rau and Stouraitis (2010), and Shi, Xu and Zhang (2018) find negative effects. Cheung, Rau and Stouraitis (2010), in particular, report correlations consistent with our finding of a negative effect on value through politically-connected directors, but not government ownership alone, in Chinese publicly listed firms. Shi, Xu and Zhang (2018) exploit a regulatory change forbidding incumbent and former politicians to accept appointments as independent directors in listed firms in China as an exogenous shock to the presence of politically-connected directors on the boards. None of these studies considers new, exogenously assigned political connections though, and thus cannot deal with the sample selection concern described above.

\section{Natural experiment and data}

In this section we describe the setup and data for our empirical exercise and discuss how we can exploit changes in Argentina's pension system as a source of exogenous variation in a firm's political connections. According to the results in Faccio (2006: 369), "connections are [more] common in the [absence] of more stringent regulation of political conflicts of interest, and connections are particularly common in countries that are perceived as being highly corrupt." In Transparency International's frequently cited Corruption Perceptions Ranking, Argentina ranked 78 th out of the 180 countries surveyed in 2020 (109/180 in 2008). ${ }^{3}$ Argentina thus seems to be a good lab in which to examine the question of firms' political connections.

\footnotetext{
${ }^{3}$ https://www.transparency.org/en/cpi/2020/, https://www.transparency.org/en/cpi/2008.
} 


\subsection{A brief history of Argentina's pension system up to 2008}

With the first pension schemes created early in the 20th century, Argentina was one of the first countries in the world to establish a social security system (Cohan, Díaz-Frers and Levy-Yeyati, 2010). At first, coverage was limited to workers of some industries and most funds were organized under an individual capitalization scheme. By the 1950s, however, social security was made universal and most of the previously existing funds were consolidated at the national level under a pay-as-you-go system - that is, an unfunded system in which current contributors pay the expenses for current recipients. For more than 30 years the system was based on intergenerational solidarity, but its increasing deficits made it undergo many changes in its design and regulation. ${ }^{4}$

In the 1980s the financial unsustainability of Argentina's pay-as-you-go pension system became evident. Tax evasion, population aging, and rising unemployment and informality in labor markets, together with other economic problems faced by the country, eroded the public support of the scheme and laid the foundations for a deep reform that took place in 1993.

Trying to achieve long-term sustainability of the pension system, a law passed towards the end of 1993 (Law No. 24,241) established a mixed system (the Sistema Integrado de Jubilaciones y Pensiones - SIJP) in which workers' contributions accumulated in individual capitalization accounts, and employers' contributions funded a universal pension that preserved the logic of the pay-as-you-go scheme (Cohan, Díaz-Frers and Levy-Yeyati, 2010). The management of the individual capitalization scheme was delegated to private firms - the pension fund managers, called Administradoras de Fondos de Jubilaciones y Pensiones (AFJPs), which were entitled to remuneration by charging commissions to their beneficiaries. Law No. 24,241 (articles $74^{\circ}$ to $76^{\circ}$ ) allowed the AFJPs to invest their funds in negotiable debt instruments, government-issued securities,

\footnotetext{
${ }^{4}$ For a detailed account of the history of Argentina's social security system, see Cetrángolo and Grushka (2004), and Isuani (2008).
} 
fixed-term deposits, shares in mutual funds, mortgage bonds, and-most important for our purposes in this paper-shares in domestic firms.

\subsection{The 2008 nationalization of Argentina's pension system}

The existence of the AFJPs came to an end in 2008. In October, an unexpected announcement by President Cristina Fernández de Kirchner started the rapid legislative process that would lead to the nationalization of Argentina's private pension funds: only 31 days passed between the announcement (October 21) and the passing (November 21) of the law (Law No. 26,425). ${ }^{5}$ The Congress undid the 1993 reform by unifying the two co-existing schemes into a single pay-as-yougo, government-run scheme - the newly created Sistema Integrado Previsional Argentino (SIPA) that replaced the SIJP.

The new law transferred all of the AFJPs' assets to a fund, the Fondo de Garantía de Sustentabilidad (FGS), run by the government through the national social security agency, Administración Nacional de la Seguridad Social (ANSES). These funds totaled over 23 billion dollars. ${ }^{6}$ The reform also implied that the government would receive the monthly flow of workers' contributions previously going to the AFJPs, which had added up to a grand total of 2.7 billion dollars in 2007, and were expected to grow over 50\% in 2008 (UADE, 2008). While the government claimed the 2008 reform to be a "strategic decision" taken to preserve workers' savings in the midst of the global financial crisis, ${ }^{7}$ political opponents saw it as an opportunity that would allow the government to gain access to new revenue sources to cover 2009 funding needs. ${ }^{8}$

\footnotetext{
${ }^{5}$ La Nación, a leading Argentine newspaper, described it as a "process that would blush the fast track obtained by the government of George W. Bush from the American Parliament" (http://www.lanacion.com.ar/1072498-es-ley-laestatizacion-de-las-jubilaciones).

${ }^{6}$ According to OSS (2011), the funds managed by the AFJPs totaled 80,209,124,682 pesos as of December 9, 2008. We have converted this figure into US dollars using the prevailing exchange rate at the time (source: http://www.cotizaciondolar.com.ar/cotizaciones dolar historico.php).

${ }^{7}$ See, e.g., http://www.laprensa.com.ar/NotePrint.aspx?Note=325886.

8 See, e.g., http://www.ucrcapital.org.ar/views/1543/oposicion-en-argentina-se-movilizo-contra-reforma-en-fondosjubilatorios. As it turns out, a large part of the new flow of funds was used to finance a conditional cash transfer program
} 
Of the 23 billion dollars managed by the AFJPs, approximately $6 \%$ consisted of shares in 43 different publicly listed firms at the time of nationalization. Ownership in a given firm by any individual AFJP was typically very small. However, the nationalization of the pension system placed all the shares in the hands of a single owner: the Argentine government (through ANSES), which suddenly became a larger shareholder in some of those firms. The mean shareholding was $13.86 \%$, but the government's ownership ranged from $0.01 \%$ to $26.96 \%$.

Depending on each firm's corporate statute and the size of the government's shareholding, the government acquired the right to appoint one or more directors to the boards of some of those firms (in particular, the government could potentially appoint directors in 21 of the 43 firms at nationalization), and this was unrelated to the reasons for the reform of the pension system. This gives us also a plausible source of exogenous variation in board composition.

\subsection{Data}

This study considers all firms listed in the Buenos Aires Stock Exchange in the period from December 2003 to November 2013 (i.e., \pm 5 years around the nationalization). ${ }^{9}$ After dropping firms with missing values in our main dependent variable, we are left with an estimation sample of 7,248 firm-month observations, corresponding to 68 firms. Table 1 presents summary statistics for our main variables.

[Table 1 about here]

The main outcome of interest is firm value, which we measure through a firm's ordinary stock price. Historical stock data were obtained from Bolsar, the financial website of the Buenos Aires

(Asignación Universal por Hijo) and an extension of pension coverage to individuals who had not made the required contributions during their work life. The stock, on the other hand, did not see much change after nationalization (see Cohan, Díaz-Frers, and Levy-Yeyati, 2010; and Basualdo et al., 2009).

${ }^{9}$ All of the results below are robust to considering different time windows around the nationalization (please see the Appendix). 
Stock Exchange. ${ }^{10}$ Since some shares trade infrequently, we compute monthly averages of daily closing prices in the Buenos Aires Stock Exchange for each firm, and normalize all prices to 1 in December 2007 for comparability across firms (Prices); i.e., we measure price growth compared to a baseline period. ${ }^{11}$ Market valuations summarize the influence of political connections through different channels as long as stock prices adjust to reflect new information on the expected profitability of listed firms (see, e.g., Roberts, 1990; and Jayachandran, 2006).

With the stock data from Bolsar we also compute two other firm-specific variables to be used in the analysis below: liquidity and volatility. Liquidity is measured as the number of days in which a firm's stock was traded within a month. We use the standard deviation of the firm's daily stock return during the month to compute a measure of realized volatility (see, e.g., Hassan et al., 2019).

We have two direct measures of a firm's political connections: government ownership and government-appointed directors. Because current shareholdings and actual appointments could be endogenous to firm value, we use the shareholdings and the right to appoint directors obtained at nationalization (and not current shareholdings or the effective exercise of that right thereafter) to build two dummy variables that capture the existence of a political connection thus defined. In the next section, we exploit the nationalization of the pension system as an exogenous shock to political connections to estimate the causal effect of having political connections on firm value. ${ }^{12}$

We obtain the list of firms in which the government acquired shares at the time of the nationalization, and the list of firms in which the government could appoint at least one director to the board from the FGS. ${ }^{13}$ We have two treatment groups: in the first group, treated firms are the 20

\footnotetext{
${ }^{10}$ See www.bolsar.com.

${ }^{11}$ Using a different baseline period (e.g., the time of treatment) to normalize prices would not change our results.

${ }^{12}$ Notice that, by virtue of our experimental design, these connections are orthogonal to any preexisting political connections.

${ }^{13}$ See http://fgs.anses.gob.ar/.
} 
firms in which the government only acquired a positive shareholding; and in the second group, treated firms are those in which the government also acquired a right to be represented on the board as of December 2008 (17 firms). Because a positive shareholding is necessary to have a right to appoint directors, these treatments are nested. ${ }^{14}$ Control firms (31) are those in which the government neither acquired shares, nor the right to appoint directors.

\section{Empirical strategy and results}

We are interested in testing whether political connections affect the market value of connected firms. The ideal experiment to test this would consist of assigning political connections to a random subset of firms. A simple comparison of the difference in the market value of firms with and without political connections would provide an estimate of the causal effect of connections on firm value. Unfortunately, such an experiment would be unfeasible in practice. By exploiting the exogenous shock of the pension system described in the previous section, our research design comes as close as possible to the ideal experiment. Given that we have panel data, we can also resort to more elaborate comparisons involving double differences.

We have identified politically-connected firms as those in which the government acquired a positive shareholding, and those in which the government acquired the right to be represented on the board. This provides our first-difference dimension. The second difference is across time, and is given by the date of the nationalization of the pension system. Finding an effect after nationalization on the market value of firms that are politically connected would provide us with a measure of the

\footnotetext{
${ }^{14}$ Because the right to appoint directors depends not only on the shareholding, but also on a firm's statute, the second treatment is not merely a more intense version of the first one, i.e., a proxy for a large shareholding. Actually, the point biserial correlation between the percentage of shares held by the government and its having the right to appoint directors is just 0.578 .
} 
value of the new connections to these firms (Khwaja and Mian, 2011). This is our task in this section. We begin by detailing our empirical strategy, and then we present our results.

\subsection{Empirical strategy}

To identify the effect of political connections on firm value we exploit the variability in government ownership and the composition of boards over time. Formally, we want to estimate the following difference-in-differences equation:

$$
p_{i t}=\delta_{1}\left(D_{t} * I_{1 i}\right)+\delta_{2}\left(D_{t} * I_{2 i}\right)+\alpha_{i}+\mu_{t}+\varepsilon_{i t}
$$

where $p_{i t}$ is the stock price (Prices in the tables below) of firm $i$ in month $t ; D_{t}$ is a dummy equal to 1 from December 2008 on (Post law); $I_{1 i}$ is a dummy equal to 1 if the government acquired a positive shareholding in firm $i$ at nationalization (Government ownership); $I_{2 i}$ is a dummy equal to 1 if the government acquired a right to appoint at least one director to the board of firm $i$ (Government directors); $\alpha_{i}$ is a firm fixed effect; $\mu_{t}$ is a month fixed effect; and $\varepsilon_{i t}$ is the usual error term. ${ }^{15}$ Fixed effects allow us to control for any time-invariant unobserved heterogeneity across firms and also for shocks common to all firms in a given time period. In this equation the parameters of interest are $\delta_{1}$ and $\delta_{2}$. In some specifications we also include industry-specific nonparametric time trends to control for economic cycles in different industries. ${ }^{16}$ Since there might be a potential correlation between month-to-month observations for the same firm, in all regressions we cluster standard errors at the firm level.

Identification exploits the unexpected pension system reform that varied the political connections across different firms. Given that government participation in some firms was the result

\footnotetext{
${ }^{15}$ We do not control for factors that are usually employed in the literature - like leverage, size, and profitability - in the regressions because they are all outcomes potentially affected by the treatments and would constitute bad controls (Angrist and Pischke, 2009).

${ }^{16}$ We use the Fama and French 10-industry classification (https://mba.tuck.dartmouth.edu/pages/faculty/ken.french/ Data_Library/det_10_ind_port.html).
} 
of political and economic decisions about the country's pension system, then the fact that some firms ended up having the government as a shareholder and government-appointed directors on their boards can be considered exogenous to the change in firms' market valuations, thus validating our empirical approach. It is worth noting that a standard event study design, the most chosen approach within this literature, would be inadequate in our setting given that the nationalization event arguably affected the entire Argentine stock market, rendering unfeasible the reliable estimation of normal— and, by extension, also abnormal—returns. Moreover, given the uniqueness of the event, it is not clear whether an event study would capture the market's rational expectation about the effect of the nationalization (see Wolfers and Zitzewitz, 2018).

Figure 1 depicts the evolution of the average monthly stock prices of treated and control firms in our sample period, and anticipates the main empirical result of the paper. Panel A compares firms in which the government acquired a positive shareholding at nationalization, but not the right to appoint directors (ownership treatment group), to firms with neither government ownership nor directors (control group). Panel B compares firms with a positive government shareholding and in which the government acquired a right to appoint directors (directors treatment group) to firms with neither government ownership nor directors (control group). The levels and the trends of the average prices in the two groups of firms are remarkably similar in the pre-nationalization period in both panels, and only start to diverge significantly after the nationalization in the case of the directors treatment. $^{17}$

Panel B also suggests that this event was difficult to interpret and price in at the moment the nationalization occurred, as it took over two years for the price difference between groups to peak.

\footnotetext{
${ }^{17}$ In regressions reported in the Appendix, we find that the common-trend assumption is verified in our sample. Whether using a linear trend or separate month dummies, we can never reject the hypothesis that pre-nationalization trends are the same for the eventually treated and control firms - thus providing additional confidence on our research design.
} 
This is consistent with the unique nature of the shock, which rendered past experience of market participants relatively irrelevant to update their expectations on future firm performance. Moreover, the evidence also suggests that an adequate analysis meant to gauge the effect of nationalization on firm value should extend for several years, as opposed to only days or weeks centered around the announcements.

Given that our data panel is unbalanced, Figure 1 should be interpreted with caution, as composition effects might be at work. However, the formal results of the next section show that the simple message the figures send holds when appropriately dealing with those effects.

[Figure 1 about here]

\subsection{Political connections and firm value}

Table 2 reports estimates of equation (1) with and without industry trends. In both cases only the coefficient on the directors treatment is statistically significant at the usual levels of confidence. We find no effect on firm value of just having the government come on board as a shareholder, and a large negative effect of having the government on the board: firms in this group have a normalized price 23 to $40 \%$ lower than control firms after the nationalization (evaluated at the sample mean). To sum up, political connections seem to be detrimental to firm value (as perceived by the market), but only when these connections operate through the possibility of having government directors appointed to the board of the firm. ${ }^{18} \mathrm{We}$ explore this finding further in the next section.

[Table 2 about here]

\footnotetext{
${ }^{18}$ Given the relatively small number of firms, a natural concern is that the effect could be driven by a few outliers. To address this concern, we have excluded the bottom quartile of treated firms, and the two worst performers in the treatment group and the two top performers in the control group, and in every case we find very similar results. Excluding firms one by one also yields estimated coefficients that are remarkably stable. These results (available upon request) strongly suggest that the effect is not driven by outliers.
} 


\section{Discussion}

Having established a causal link between (potential) government representation on boards and reductions in firm value, we now move on to explore that link further.

\subsection{Alternative explanations}

\subsubsection{Liquidity}

The relatively poorer stock performance of politically-connected firms could alternatively be explained by a larger, negative shock to the liquidity of those stocks after the nationalization. Specifically, it could be the case that stocks of such firms were also ex ante more heavily traded by the AFJPs, since the larger aggregate holdings that allow the appointment of directors may suggest higher interest in those firms. Given that the nationalization implied the end of trading by the AFJPs, those stocks could have suffered a larger shock to their market liquidity, which in time could have lowered their prices. To explicitly examine this possibility, we run regressions similar to equation (1), but replace prices on the left-hand side with a measure of liquidity - the number of days in which a firm's stock was traded within a month. As can be seen in Table 3 below, we find no support for a liquidity effect as an explanation for the results presented in Table 2. The coefficients reported in columns (1) and (2) are economically negligible and statistically nonsignificant.

\subsubsection{Lower cash flows or riskier cash flows?}

Absent a liquidity effect, the fall in stock prices that we observe could be due to a reduction in expected cash flows, an increase in their perceived riskiness, or both. Provided that increased risk is reflected in increased market volatility of the firm's stock return (Hassan et al., 2019), we can use this volatility on the left-hand side of a regression like equation (1) to better understand the drivers of our main results. Following Bloom, Bond and Van Reenen (2007), and Hassan et al. (2019), we measure volatility as the standard deviation of the firm's daily stock return during the month. 
As reported in columns (3) and (4) of Table 3, the effect of either treatment on volatility is essentially zero, leaving changes in expected cash flows as the most likely reason why political connections affect firm value. Since we do not have data on cash flows to address the matter more directly, this claim is tentative and should be interpreted with caution.

[Table 3 about here]

\subsection{Costs and benefits of politically-connected directors}

We have seen in the previous section that compared to the control group, only firms in which government ownership is accompanied by a right to appoint directors experience a negative effect on their market value after the nationalization of the pension system. This result is best seen as a net effect, because politically-connected directors can bring both costs and benefits to the firm.

A growing literature has been documenting the benefits from having political connections in general. Politically-connected firms enjoy easier access to credit (Claessens, Feijen, and Laeven, 2008; Dinç, 2005; Johnson and Mitton, 2003; Khwaja and Mian, 2005), lighter regulation (Agrawal and Knoeber, 2001; De Figueiredo and Edwards, 2007; Kroszner and Stratmann, 1998), favorable access to government contracts (Amore and Bennedsen, 2013; Auriol, Straub, and Flochel, 2016; Baltrunaite, 2020; Cingano and Pinotti, 2013; Goldman, Rocholl, and So, 2013; Titl and Geys, 2019), lower taxation (Faccio, 2010), and government aid in case of financial trouble (Faccio, Masulis, and McConnell, 2006)— to name just a few benefits. Politically-connected board members, in particular, could bring value to the firm (especially when they are government officials), for instance, by helping the firm with their knowledge of government procedures and the public policy environment; they could also contribute privileged access to (and influence on) government decision makers (Agrawal and Knoeber, 2001; Goldman, Rocholl and So, 2009; Hillman, 2005; Hillman, Cannella and Paetzold, 2000; and Lester et al., 2008). 
Political connections might also entail some costs to firms. Politicians can extract rents from connections by interfering with the regular management of a business - a general point made in Shleifer and Vishny $(1994,1998)$. We maintain that political connections are more likely to be detrimental to firm value when they grant the government an increased ability to interfere with firm regular activities (as is arguably the case with the CEOs in Bertrand et al., 2018, or Fan et al., 2007; with the controlling State ownership in Chen et al., 2017; or with the government's presence on the board in this paper), than in the case of political connections whose nature entail a good will between firm and government (like those based on personal ties or money contributions to individual candidates or political parties). ${ }^{19}$

Politically-connected firms could sub-optimally increase employment (Bertrand et al., 2018; Carvalho, 2014) or capital expenditure (Alok and Ayyagari, 2020) to help politicians' electoral efforts. By the same token, they could likewise decrease product prices sub-optimally, especially for products with a significant effect on the electorate's opinion, such as utilities and food. ${ }^{20}$

Politically-connected directors could also pursue politically-driven goals potentially at odds with the profit maximization purpose of the firm, imposing costs on firm value. For example, the director appointed by the government at Siderar (a large steel manufacturer) stated that he would have "an active role", and that "government representatives must follow national policy guidelines, [...], i.e., take the national development policy inside the private firm". ${ }^{21}$

\footnotetext{
${ }^{19}$ This is also in line with Frye and Iwasaki (2011), who argue that government influence on firm behavior is best captured by the government's representation on the board than through government ownership in transition and developing economies.

20 Commentators in Argentina believed this to be a concrete possibility (see, e.g., https://www.iprofesional.com/legales/81389-que-decisiones-clave-pueden-tomar-los-directores-estatales-en-lasempresas-privadas)

$21 \quad$ https://www.iprofesional.com/legales/81389-que-decisiones-clave-pueden-tomar-los-directores-estatales-en-lasempresas-privadas (our translation).
} 
Yet another decision that could be altered by government-appointed directors is the decision about dividend payments. For instance, government representatives on the board could force higher dividends (or lower retention) than optimal reinvestment would require in order to increase available funds. ${ }^{22}$ In Transportadora de Gas del Sur (the largest gas supplier in Argentina), the governmentappointed directors proposed dividend payments of over $\$ 976$ million pesos in 2011 , well above the $\$ 40$ million originally proposed by the board. ${ }^{23}$

Goldman, Rocholl and So (2009), and Shi, Xu and Zhang (2018) also focus on the political connections of the board of directors, and explore the impact of these connections on the value of publicly traded U.S. and Chinese companies, respectively. These studies find a positive effect of politically-connected directors in the U.S., but a negative effect in China. As pointed out by Faccio (2010), the magnitude of the benefits of political ties might depend on the specific country of analysis. Hence it would be interesting to know how much of this difference in results is explained by the very different institutional environments of Argentina, the U.S., and China. ${ }^{24}$ Furthermore, sample selection could also be part of the explanation: Goldman, Rocholl and So (2009) measure political connections through past political appointments of current directors, which are arguably desired connections; whereas Shi, Xu and Zhang (2018) exploit a regulatory change that forced incumbent political directors (like National People's Congress officials), who probably represented connections that could not be avoided before the change, out of the board. Unfortunately, the relative

\footnotetext{
${ }^{22}$ Of course, it could be the case that payout policy was not optimal to begin with, and politically-connected directors are forcing higher dividend payments to mitigate existing agency problems, for instance, by reducing free cash flow (see, e.g., DeAngelo, DeAngelo, and Stulz, 2006; and Jensen, 1986). Such a change should be beneficial for firm value. However, the evidence in Table 2 provides no support for this alternative explanation.

23 https://www.infobae.com/2011/04/29/578695-la-anses-designa-cinco-directores-mas-empresas-cotizantes/?output Type=amp-type.

${ }^{24}$ Claessens, Feijen, and Laeven (2008), and Li et al. (2008) argue that in countries with low institutional development the value of connections is likely greater that in more developed countries, whereas Fan, Wong and Zhang (2007) predict exactly the opposite.
} 
importance of institutional factors and sample selection in explaining the different results is hard to ascertain with the data at hand.

\section{Conclusion}

In this paper we exploit a unique natural experiment that gives us exogenous assignment of new political connections to firms to establish a causal link from political connections to reductions in firm value. This is in stark contrast to most previous studies of this link, which tend to find that connections are valuable to firms. We argue that sample selection might be partly responsible for the difference: if firms actively seek or try to avoid political connections, measuring existing connections might introduce sample selection because the connections that are observed and measured should be, on average, those that create most value to firms.

The analysis concentrates on private, publicly-traded firms, and shows that political connections are viewed by the market as destroying value, but only when connections provide the government with the possibility of exerting larger influence through the appointment of directors to the corporate board. The overall evidence is consistent with the grabbing-hand argument of Shleifer and Vishny $(1994,1998)$ that private enterprises subject to political influence pursue political goals that are not consistent with firm value maximization (see also the literature on government intervention and rent seeking; e.g., Agrawal and Knoeber, 2001; Fan, Wong, and Zhang, 2007; Hadlock, Lee, and Parrino, 2002; and Helland and Sykuta, 2004). Our main result cannot be explained by reductions in stock liquidity or increases in the market volatility of a firm's stock return, leaving reductions in expected cash flows to equity as a plausible explanation.

Our results on the role of government-appointed directors are important in light of the increasing presence of politicians on corporate boards all over the world, especially in the wake of 
the Great Recession (see, e.g, Goldman, Rocholl and So, 2013; Lester et al., 2008; and Shi, Xu and Zhang, 2018). Since in many countries the state still exerts significant influence on managerial decision-making in large firms (Frye and Iwasaki, 2011), a better understanding of the effects and mechanics of this influence is surely desirable (Megginson and Netter, 2001; Iwasaki, 2007).

Although the analysis was carried out for a single country, we believe that the results for Argentina apply to many other countries around the world with weak institutional environments or high corruption. ${ }^{25}$ Argentina was deemed in 2020 to have stronger institutions than countries like Brazil, China, Mexico, Ukraine, Russia, Pakistan, and Bangladesh. ${ }^{26}$ It was also perceived as being less corrupt than, among others, Brazil, Egypt, Ukraine, Pakistan, Mexico, Russia, and Bangladesh; and as corrupt as South Africa, China, India and Turkey. ${ }^{27}$ As previously pointed out by Fisman (2001: 1101), "[t]o the extent that perceived corruption is a reasonable proxy for the prevalence of political rents, the results of this paper suggest that political connections may play an important role in many of the world's largest and most important economies."

\footnotetext{
${ }^{25}$ Political connections could be important even in countries with a well-functioning legal system and low corruption, as shown by Goldman, Rocholl, and So (2009) for the United States, and Amore and Bennedsen (2013) for Denmark.

${ }^{26}$ Based on the World Bank's Worldwide Governance Indicators (https://info.worldbank.org/governance/wgi/).

${ }^{27}$ https://www.transparency.org/en/cpi/2020/.
} 


\section{References}

Adams, Renée B., Ferreira, Daniel, 2009. Women in the boardroom and their impact on governance and performance. Journal of Financial Economics 94(2), pp. 291-309.

Adams, Renée B., Hermalin, Benjamin E., Weisbach, Michael S., 2010. The role of boards of directors in corporate governance: a conceptual framework and survey. Journal of Economic Literature 48(1), 58-107.

Agrawal, Anup, Knoeber, Charles R., 2001. Do some outside directors play a political role? Journal of Law and Economics 44(1), 179-198.

Akey, Pat, Lewellen, Stefan, 2017. Policy uncertainty, political capital, and firm risk-taking. Available at SSRN: https://ssrn.com/abstract=2758395 or http://dx.doi.org/10.2139/ssrn.2758395.

Alok, Shashwat, Ayyagari, Meghana, 2020. Politics, state ownership, and corporate investments. Review of Financial Studies 33(7), 3031-3087.

Amore, Mario D., Bennedsen, Morten, 2013. The value of local political connections in a lowcorruption environment. Journal of Financial Economics 110(2), 387-402.

Angrist, Joshua D., Pischke, Jörn-Steffen, 2009. Mostly Harmless Econometrics. An Empiricist's Companion. Princeton University Press, Princeton, NJ.

Auriol, Emmanuelle, Straub, Stéphane, Flochel, Thomas, 2016. Public procurement and rentseeking: the case of Paraguay. World Development 77, 395-407.

Baltrunaite, Audinga, 2020. Political contributions and public procurement: evidence from Lithuania. Journal of the European Economic Association 18(2), 541-582.

Basualdo, Eduardo, Arceo, Nicolás, González, Mariana, Mendizábal, Nuria, 2009. La evolución del sistema previsional argentino. Documento de Trabajo No. 2, Centro de Investigación y Formación de la República Argentina (CIFRA), November. 
Bertrand, Marianne, Kramarz, Francis, Schoar, Antoinette, Thesmar, David, 2018. The cost of political connections. Review of Finance 22(3), 849-876.

Bloom, Nick, Bond, Stephen, Van Reenen, John, 2007. Uncertainty and investment dynamics. The Review of Economic Studies 74(2), 391-415.

Bortolotti, Bernardo, Faccio, Mara, 2009. Government control of privatized firms. The Review of Financial Studies 22(8), 2907-2939.

Boubakri, Narjess, Cosset, Jean-Claude, Saffar, Walid, 2008. Political connections of newly privatized firms. Journal of Corporate Finance 14(5), 654-673.

Carvalho, Daniel R., 2014. The real effects of government owned-banks: evidence from an emerging market. Journal of Finance 69(2), 577-609.

Cetrángolo, Oscar, Grushka, Carlos, 2004. Sistema previsional argentino: crisis, reforma y crisis de la reforma. Serie Financiamiento del Desarrollo No. 151, CEPAL, United Nations, December.

Chen, Carl R., Li, Yingqi, Luo, Danglun, Zhang, Ting, 2017. Helping hands or grabbing hands? An analysis of political connections and firm value. Journal of Banking and Finance 80, 7189.

Cheung, Yan-Leung, Rau, P. Raghavendra, Stouraitis, Aris, 2010. Helping hand or grabbing hand? Central vs. local government shareholders in Chinese listed firms. Review of Finance 14(4), 669-694.

Cingano, Federico, Pinotti, Paolo, 2013. Politicians at work: the private returns and social costs of political connections. Journal of the European Economic Association 11(2), 433-465.

Claessens, Stijn, Feijen, Erik, Laeven, Luc, 2008. Political connections and preferential access to finance: the role of campaign contributions. Journal of Financial Economics 88(3), 554-580. 
Cohan, Luciano, Díaz-Frers, Luciana, Levy-Yeyati, Eduardo, 2010. Lineamientos para una reforma previsional. Documento de Trabajo No. 50, Centro de Implementación de Políticas Públicas para la Equidad y el Crecimiento (CIPPEC), September.

Cooper, Michael J., Gulen, Huseyin, Ovtchinnikov, Alexei V., 2010. Corporate political contributions and stock returns. The Journal of Finance 65(2), 687-724.

DeAngelo, Harry, DeAngelo, Linda, Stulz, René M., 2006. Dividend policy and the earned/contributed capital mix: a test of the life-cycle theory. Journal of Financial Economics 81(2), $227-254$.

De Figueiredo Jr, Rui J. P., Edwards, Geoff, 2007. Does private money buy public policy? Campaign contributions and regulatory outcomes in telecommunications. Journal of Economics and Management Strategy 16(3), 547-576.

Dinç, I. Serdar, 2005. Politicians and banks: political influences on government-owned banks in emerging markets. Journal of Financial Economics 77(2), 453-479.

Faccio, Mara, 2006. Politically connected firms. The American Economic Review 96(1), 369386.

Faccio, Mara, 2010. Differences between politically connected and nonconnected firms: a cross-country analysis. Financial Management 39(3), 905-927.

Faccio, Mara, Masulis, Ronald W., McConnell, John J., 2006. Political connections and corporate bailouts. The Journal of Finance 61(6), 2597-2635.

Faccio, Mara, Parsley, David C., 2009. Sudden deaths: taking stock of geographic ties. Journal of Financial and Quantitative Analysis 44(3), 683-718.

Fan, Joseph P. H., Wong, T. J., Zhang, Tianyu, 2007. Politically connected CEOs, corporate governance, and post-IPO performance of China's newly partially privatized firms. Journal of 
Financial Economics 84(2), 330-357.

Ferguson, Thomas, Voth, Hans-Joachim, 2008. Betting on Hitler: the value of political connections in Nazi Germany. The Quarterly Journal of Economics 123(1), 101-137.

Fisman, Raymond, 2001. Estimating the value of political connections. The American Economic Review 91(4), 1095-1102.

Frye, Timothy M., Iwasaki, Ichiro, 2011. Government directors and business-state relations in Russia. European Journal of Political Economy 27(4), 642-658.

Goldman, Eitan, Rocholl, Jörg, So, Jongil, 2009. Do politically connected boards affect firm value? The Review of Financial Studies 22(6), 2331-2360.

Goldman, Eitan, Rocholl, Jörg, So, Jongil, 2013. Politically connected boards of directors and the allocation of procurement contracts. Review of Finance 17(5), 1617-1648.

Güner, A. Burak, Malmendier, Ulrike, Tate, Geoffrey, 2008. Financial expertise of directors. Journal of Financial Economics 88(2), 323-354.

Hadlock, Charles J., Lee, D. Scott, Parrino, Robert, 2002. CEO careers in regulated environments: evidence from Electric and gas utilities. Journal of Law and Economics 45(2), 535563.

Harrison, Ann, Meyer, Marshall, Wang, Peichun, Zhao, Linda, Zhao, Minyuan, 2019. Can a tiger change its stripes? Reform of Chinese state-owned enterprises in the penumbra of the state. Working Paper 25475, National Bureau of Economic Research, January. Available at http://www.nber.org/papers/w25475.

Hassan, Tarek A., Hollander, Stephan, Van Lent, Laurence, Tahoun, Ahmed, 2019. Firm-level political risk: measurement and effects. The Quarterly Journal of Economics 134(4), 2135-2202.

Helland, Eric, Sykuta, Michael, 2004. Regulation and the evolution of corporate boards: 
monitoring, advising or window dressing? Journal of Law and Economics 47(1), 167-194.

Hermalin, Benjamin E., Weisbach, Michael S., 2003. Boards of directors as an endogenously determined institution: a survey of the economic literature. Federal Reserve Bank of New York Economic Policy Review 9(1), 7-26.

Hillman, Amy J., 2005. Politicians on the board of directors: do connections affect the bottom line? Journal of Management 31(3), 464-481.

Hillman, Amy J., Cannella, Albert A., Paetzold, Ramona L., 2000. The resource dependence role of corporate directors: strategic adaptation of board composition in response to environmental change. Journal of Management Studies 37(2), 235-255.

Isuani, Ernesto Aldo, 2008. La política social argentina en perspectiva. In: Cruces, Moreno, Ringold, Rofman (Eds.), Los Programas Sociales en Argentina hacia el Bicentenario. Visiones y perspectivas. World Bank, Washington, Available at http://documents.worldbank.org/curated/en/651311468210566492/Los-programas-sociales-enArgentina-hacia-el-Bicentenario-Visiones-y-perspectivas.

Iwasaki, Ichiro, 2007. Enterprise reform and corporate governance in Russia: a quantitative survey. Journal of Economic Surveys 21(5), 849-902.

Jayachandran, Seema, 2006. The Jeffords effect. Journal of Law and Economics 49(2), 379425.

Jensen, Michael C., 1986. Agency costs of free cash flow, corporate finance, and takeovers. The American Economic Review 76(2), 323-329.

Johnson, Jonathan L., Daily, Catherine M., Ellstrand, Alan E., 1996. Boards of directors: a review and research agenda. Journal of Management 22(3), 409-438.

Johnson, Simon, Mitton, Todd, 2003. Cronyism and capital controls: evidence from Malaysia. 
Journal of Financial Economics 67(2), 351-382.

Khwaja, Asim Ijaz, Mian, Atif, 2005. Do lenders favor politically connected firms? Rent provision in an emerging financial market. The Quarterly Journal of Economics 120(4), 1371-1411. Khwaja, Asim Ijaz, Mian, Atif, 2011. Rent seeking and corruption in financial markets. Annual Review of Economics 3, 579-600.

Kroszner, Randall S., Stratmann, Thomas, 1998. Interest-group competition and the organization of Congress: theory and evidence from financial services' Political Action Committees. The American Economic Review 88(5), 1163-1187.

Kung, James Kai-Sing, Ma, Chicheng, 2018. Friends with benefits: how political connections help to sustain private enterprise growth in China. Economica 85(337), 41-74.

Lester, Richard, Hillman, Amy A., Zardkoohi, Asghar, Canella, Albert A., 2008. Former government officials as outside directors: the role of human and social capital. Academy of Management Journal 51(5), 999-1013.

Li, Hongbin, Meng, Lingsheng, Wang, Qian, Zhou, Li-An, 2008. Political connections, financing and firm performance: evidence from Chinese private firms. Journal of Development Economics 87(2), 283-299.

Masulis, Ronald W., Ruzzier, Christian A., Xiao, Sheng, Zhao, Shan, 2012. Do independent expert directors matter? MPRA Paper No. 68200, Munich Personal RePEc Archive, June. Available at https://mpra.ub.uni-muenchen.de/id/eprint/68200.

Megginson, William L., Netter, Jeffry M., 2001. From state to market: a survey of empirical studies on privatization. Journal of Economic Literature 39(2), 321-389.

OSS, 2011. Caracterización del Fondo de Garantía de Sustentabilidad del SIPA. Observatorio de la Seguridad Social, Administración Nacional de la Seguridad Social, Argentina, May. Available 
at http://observatorio.anses.gob.ar/.

Palanský, Miroslav, 2021. The value of political connections in the post-transition period: evidence from Czechia. Public Choice 188:121-154.

Ramalho, Rita, 2007. The persistence of corruption: evidence from the 1992 presidential impeachment in Brazil. Unpublished manuscript, The World Bank, January.

Roberts, Brian E., 1990. A dead senator tells no lies: seniority and the distribution of federal benefits. American Journal of Political Science 34(1), 31-58.

Shi, Haina, Xu, Haoping, Zhang, Xin, 2018. Do politically connected independent directors create or destroy value? Journal of Business Research 83, 82-96.

Shleifer, Andrei, 1998. State versus private ownership. Journal of Economic Perspectives 12(4), 133-150.

Shleifer, Andrei, Vishny, Robert W., 1994. Politicians and firms. The Quarterly Journal of Economics 109(4), 995-1025.

Shleifer, Andrei, Vishny, Robert W., 1998. The Grabbing Hand. Government Pathologies and Their Cures. Harvard University Press, Cambridge, MA.

Tian, Lihui, Estrin, Saul, 2008. Retained state shareholding in Chinese PLCs: does government ownership always reduce corporate value? Journal of Comparative Economics 36(1), 74-89.

Titl, Vitezslav, Geys, Benny, 2019. Political donations and the allocation of public procurement contracts. European Economic Review 111: 443-458.

UADE, 2008. Informe AFJP. Instituto de Economía, Facultad de Ciencias Económicas, Universidad Argentina de la Empresa, September.

Wei, Zuobao, Xie, Feixue, Zhang, Shaorong, 2005. Ownership structure and firm value in China's privatized firms: 1991-2001. The Journal of Financial and Quantitative Analysis 40(1), 87- 
108.

Wolfers, Justin, Zitzewitz, Eric, 2018. The "standard error" of event studies: lessons from the 2016 election. AEA Papers and Proceedings 108, 584-589.

$\mathrm{Wu}$, Jie, 2011. Asymmetric roles of business ties and political ties in product innovation. Journal of Business Research 64(11), 1151-1156. 
Figure 1. Political connections and stock prices

Panel A. Ownership treatment

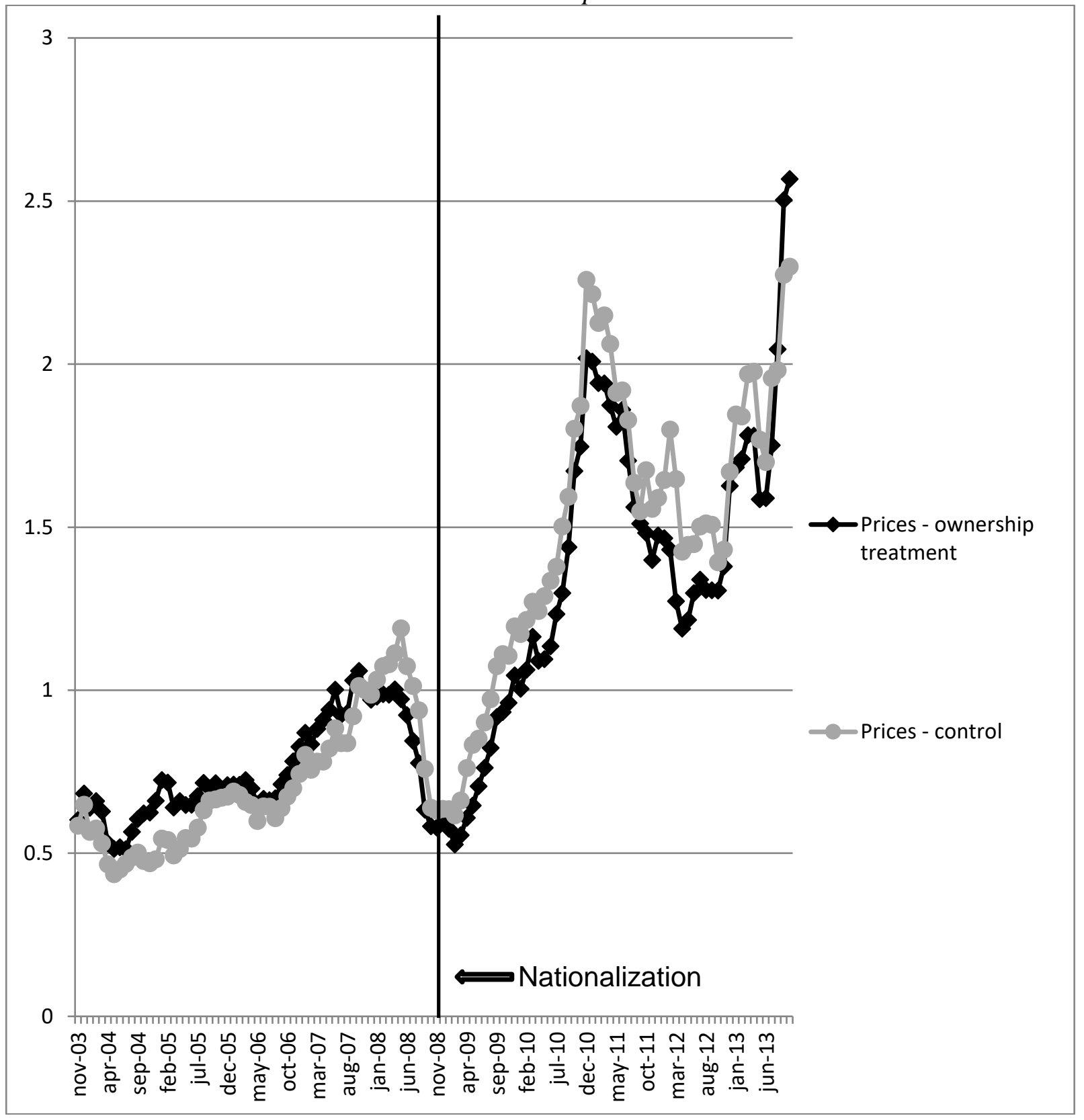




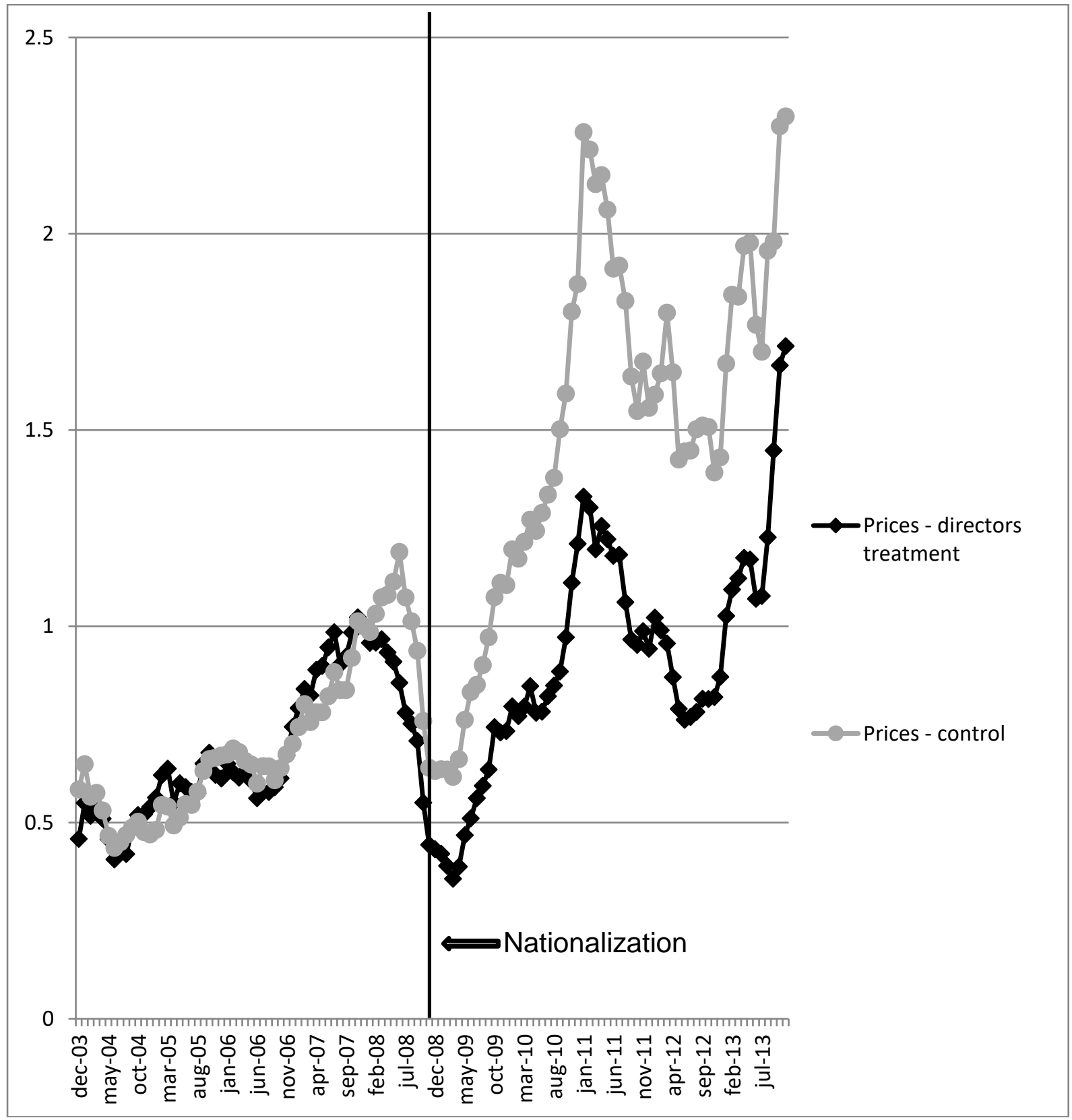

Notes: The figures depict average monthly stock prices of treated and control firms from December 2003 to November 2013, scaled by stock prices in December 2007. Panel A compares firms with government ownership but not directors (ownership treatment group) to firms with neither government ownership nor directors (control group). Panel B compares firms with government ownership and directors (directors treatment group) to firms with neither government ownership nor directors (control group). 
(1) (2)

Observations Mean
(2)

Std. Dev.

\section{Full sample (68 firms)}

Prices

Liquidity

Volatility

Government ownership

Government directors

Control group (31 firms)

Prices

Liquidity

Volatility

Ownership treatment group (20 firms)

Prices

Liquidity

Volatility

\section{Directors treatment group (17 firms)}

Prices

Liquidity

Volatility
7,248

1.030

0.804

7,248

16.360

5.610

6,759

0.025

0.014

7,248

0.559

0.497

7,248

0.260

0.439

1.128

0.908

3,196

14.750

5.923

2,868

0.026

0.015

2,169

1.079

0.841

2,169

18.261

4.120

2,128

0.025

0.013

Notes: 68 firms are observed between December 2003 and November 2013. Prices stands for a firm's monthly stock price scaled by its value in December 2007, Liquidity is the number of days in which a firm's stock was traded within a month, Volatility is the standard deviation of the firm's daily stock return during the month, Government ownership is a dummy equal to 1 if the government acquired a positive shareholding in the firm at nationalization, and Government directors is a dummy equal to 1 if the government acquired the right to appoint at least one director to the board of the firm at nationalization. 
Table 2. Political connections and firm value

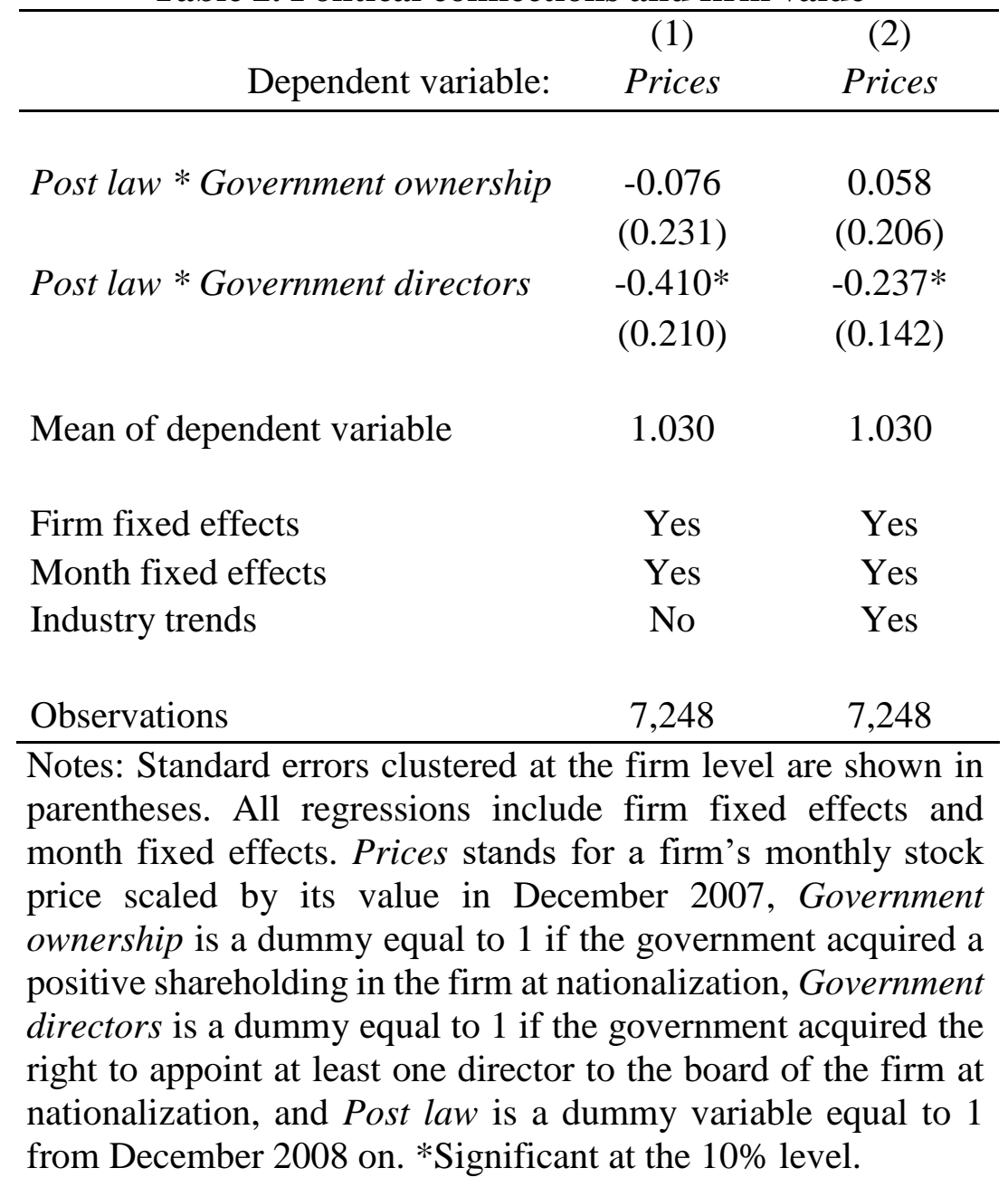


Table 3. Political connections, liquidity and risk

\begin{tabular}{|c|c|c|c|c|}
\hline Dependent variable: & $\begin{array}{c}\text { (1) } \\
\text { Liquidity }\end{array}$ & $\begin{array}{c}(2) \\
\text { Liquidity }\end{array}$ & $\begin{array}{c}(3) \\
\text { Volatility }\end{array}$ & $\begin{array}{c}(4) \\
\text { Volatility }\end{array}$ \\
\hline Post law * Government ownership & $\begin{array}{c}0.138 \\
(0.818)\end{array}$ & $\begin{array}{c}0.104 \\
(0.955)\end{array}$ & $\begin{array}{l}-0.0004 \\
(0.0015)\end{array}$ & $\begin{array}{c}-0.0004 \\
(0.0016)\end{array}$ \\
\hline Post law * Government directors & $\begin{array}{c}-0.711 \\
(1.019)\end{array}$ & $\begin{array}{c}-0.460 \\
(1.060)\end{array}$ & $\begin{array}{l}-0.0006 \\
(0.0018)\end{array}$ & $\begin{array}{c}-0.0005 \\
(0.0018)\end{array}$ \\
\hline Mean of dependent variable & 16.360 & 16.360 & 0.0249 & 0.0249 \\
\hline $\begin{array}{l}\text { Firm fixed effects } \\
\text { Month fixed effects } \\
\text { Industry trends }\end{array}$ & $\begin{array}{l}\text { Yes } \\
\text { Yes } \\
\text { No }\end{array}$ & $\begin{array}{l}\text { Yes } \\
\text { Yes } \\
\text { Yes }\end{array}$ & $\begin{array}{l}\text { Yes } \\
\text { Yes } \\
\text { No }\end{array}$ & $\begin{array}{l}\text { Yes } \\
\text { Yes } \\
\text { Yes }\end{array}$ \\
\hline Observations & 7,248 & 7,248 & 6,759 & 6,759 \\
\hline
\end{tabular}

Notes: Standard errors clustered at the firm level are shown in parentheses. All regressions include firm fixed effects and month fixed effects. Liquidity is the number of days in which a firm's stock was traded within a month, Volatility is the standard deviation of the firm's daily stock return during the month, Government ownership is a dummy equal to 1 if the government acquired a positive shareholding in the firm at nationalization, Government directors is a dummy equal to 1 if the government acquired the right to appoint at least one director to the board of the firm at nationalization, and Post law is a dummy variable equal to 1 from December 2008 on. 


\section{Appendix}

\section{Different time windows}

In the main text of the article we have considered a window of 5 years (or 60 months) on either side of the intervention (the nationalization of the AFJPs). Table A1 shows that our main results on firm value are robust to considering different windows ( \pm 6 years and \pm 4 years).

[Table A1 about here]

\section{Common-trend assumption}

Difference-in-differences estimates assume that the change in stock prices in control firms is an unbiased estimate of the counterfactual. While this assumption cannot be tested, it is possible to check whether stock prices trends in treated firms and control firms were the same in the pretreatment period. If time trends are parallel in the pre-treatment period, then it is likely that they would have continued to be parallel in the post-treatment period in the absence of the treatment. Column (1) of Table A2 shows the results of estimating a modified version of equation (1) that includes a linear trend and, instead of the treatment variables, interactions between the linear trend and dummy variables that take the value of 1 if the firm will be eventually treated (under either treatment) and 0 if the firm will never be treated, using only observations from the period prior to the nationalization of the AFJPs. In column (2) of Table A2 we have included instead separate month dummies for treated firms. If the pre-intervention trend of firms which were not treated (control group) and the pre-intervention trends of those which will eventually be treated are not significantly different, then we can be confident that the trends in the three groups would have remained similar in the absence of the intervention (thus providing validity to the assumption that the trend in the 
control group is a good counterfactual for the trend in the treated groups in the post-intervention period).

[Table A2 about here]

As reported in Table A2, for neither specification can we reject the hypothesis that preintervention trends are the same for the eventually treated and control firms. In column (1) we find that the linear trends are not significant, and in column (2) we see that all dummy variables capturing the interaction between the month effects and the dummies for the treated firms also turn out nonsignificant. Even though we are exploiting a well-documented natural experiment, the results in Table A2 provide additional confidence on the difference-in-differences assumption. Similar results (available from the authors upon request) hold when we include industry trends.

\section{Fake treatment}

In Table A3 we perform a placebo test. We restrict the sample to the pre-treatment period, assigning two different fake treatments to those firms that were eventually treated (under either treatment). We use a fake treatment variable that takes a value of one after April 2006 (roughly the mid-point in the pre-treatment period) and interact it with our measures of political connections in column (1), and another fake treatment variable that takes a value of one after December 2007 (our baseline period) in column (2). ${ }^{1}$ We report estimates for the effect of political connections on stock prices using the fake treatment and, as expected, all the coefficients associated to the fake treatment variable are much smaller than those in Table 2 in the main text, and not significantly different from zero. These findings provide additional support to the validity of our identification strategy — as expected given the exogenous variation provided by our natural experiment.

[Table A3 about here]

\footnotetext{
${ }^{1}$ We have tried with other fake dummies, with similar results (which are available upon request).
} 


\section{List of firms by treatment group}

Our sample includes 68 firms. 37 firms saw the government come on board as a shareholder after the nationalization of the AFJPs. Of these 37 firms, 17 were firms in which the government also acquired the right to be represented on the board as of December 2008 (directors treatment group); the remaining 20 firms constitute our ownership treatment group. Finally, we have 31 firms in the control group. Below we list all firms in the sample by group.

\section{Treated firms (37)}

- Ownership treatment (20)

○ Banco Patagonia S.A.

- BBVA Banco Francés S.A.

○ Capex S.A.

○ Cresud S.A.

○ Euromayor S.A.

○ Grupo Clarin S.A.

○ Grupo Financiero Galicia S.A.

○ Inversiones y Representaciones S.A.

○ IRSA Propiedades Comerciales S.A.

○ Juan Minetti S.A.

- Ledesma S.A.

○ Metrogás S.A. 
- Molinos Río de la Plata S.A.

○ Petrobras Argentina S.A.

○ Quickfood S.A.

○ S.A. San Miguel

- Telefónica de Argentina S.A.

○ Tenaris S.A.

- Transportadora de Gas del Norte

○ YPF S.A.

- Directors treatment (17)

○ Aluar Aluminio Argentino

- Banco Hipotecario

- Banco Macro S.A.

○ Camuzzi Gas Pampeana S.A.

- Distribuidora de Gas Cuyana

- Edenor S.A.

○ Empresa Distribuidora Eléctrica Regional S.A. (Emdersa)

- Endesa Costanera S.A. (Central Costanera)

- Gas Natural BAN

- Grupo Concesionario del Oeste

○ La Anónima (Importadora y Exportadora de la Patagonia S.A.) 
○ Mirgor

- Pampa Energía S.A.

○ Siderar S.A.I.C.

○ Solvay Indupa S.A.

○ Telecom Argentina

○ Transener S.A.

\section{Control firms (31)}

○ Agrometal S.A.I.

- Ángel Estrada y Cía. S.A.

- Autopistas del Sol S.A.

- Banco Río de la Plata

- Banco Santander Río S.A.

○ Bodegas Esmeralda S.A.

○ Boldt S.A.

○ Caputo S.A.I.C.F.

- Carboclor S.A.

- Carlos Casado S.A.

- Celulosa Argentina S.A.

- Cía. Argentina de Comodoro Rivadavia S.A.

- Cía. Introductora de Bs As S.A. 
○ Colorin S.A.

○ Dycasa S.A.

○ Ferrum S.A.

○ Fiplasto S.A.

○ García Reguera S.A.C.I.F.E.I.

○ Garovaglio Zorraquín

○ Grimoldi S.A.

○ Instituto Rosenbusch S.A.

- Longvie S.A.

- Molinos Juan Semino S.A.

○ Morixe Hnos. S.A.

○ Papel Prensa S.A.I.C.F. y de M.

- Petroleo Brasileiro

- Petrolera del Conosur S.A.

○ Polledo S.A.I.C. y F.

- Respsol S.A.

$\circ$ Rigolleau S.A.

- Sociedad Comercial del Plata S.A. 


\begin{tabular}{lcccc}
\hline \multicolumn{1}{c}{ Dependent variable: } & Prices & Prices & Prices & Prices \\
\hline \multirow{2}{*}{ Post law * Government ownership } & 0.130 & 0.262 & -0.094 & 0.042 \\
& $(0.300)$ & $(0.286)$ & $(0.224)$ & $(0.198)$ \\
Post law * Government directors & $-0.520^{*}$ & $-0.349 *$ & $-0.399 *$ & $-0.222^{*}$ \\
& $(0.290)$ & $(0.195)$ & $(0.202)$ & $(0.134)$ \\
Mean of dependent variable & 1.030 & 1.030 & 1.030 & 1.030 \\
& & & & \\
Firm fixed effects & Yes & Yes & Yes & Yes \\
Month fixed effects & Yes & Yes & Yes & Yes \\
Industry trends & No & Yes & No & Yes \\
Window & & & & {$[-4,+4]$} \\
Observations & {$[-6,+6]$} & {$[-6,+6]$} & {$[-4,+4]$} & \\
\hline
\end{tabular}

Notes: Standard errors clustered at the firm level are shown in parentheses. All regressions include firm fixed effects and month fixed effects. Prices stands for a firm's monthly stock price scaled by its value in December 2007, Government ownership is a dummy equal to 1 if the government acquired a positive shareholding in the firm at nationalization, Government directors is a dummy equal to 1 if the government acquired the right to appoint at least one director to the board of the firm, and Post law is a dummy variable equal to 1 from December 2008 on. *Significant at the $10 \%$ level. 


\begin{tabular}{|c|c|c|}
\hline & Dependent variable: & $\begin{array}{c}(1) \\
\text { Prices }\end{array}$ \\
\hline Trend & & $\begin{array}{c}0.0097 * * * \\
(0.0013)\end{array}$ \\
\hline Trend $x$ Government ownership & & $\begin{array}{l}-0.0027 \\
(0.0024)\end{array}$ \\
\hline Trend $x$ Government directors & & $\begin{array}{c}0.0007 \\
(0.0025)\end{array}$ \\
\hline
\end{tabular}

Dummy Dec 2003 x Government ownership (2) Prices

Dummy Jan 2004 x Government ownership

Dummy Feb 2004 x Government ownership

Dummy Mar 2004 x Government ownership

Dummy Apr 2004 x Government ownership

(0.156)

0.109

(0.149)

Dummy May 2004 x Government ownership

Dummy Jun 2004 x Government ownership

0.103

(0.120)

Dummy Jul 2004 x Government ownership

Dummy Aug 2004 x Government ownership

Dummy Sep 2004 x Government ownership

Dummy Oct 2004 x Government ownership

(0.126)

0.141

(0.131)

Dummy Nov 2004 x Government ownership

0.171

(0.132)

Dummy Dec 2004 x Government ownership

0.186

(0.131)

0.195

Dummy Jan 2005 x Government ownership

(0.133)

Dummy Feb 2005 x Government ownership

0.206

(0.137)

Dummy Mar 2005 x Government ownership

(0.136)

Dummy Apr 2005 x Government ownership

0.162

(0.125)

Dummy May 2005 x Government ownership

0.162

(0.128) 
Dummy Jun 2005 x Government ownership

(0.129)

Dummy Jul 2005 x Government ownership

0.130

$(0.125)$

Dummy Aug 2005 x Government ownership

0.132

(0.122)

Dummy Sep 2005 x Government ownership

0.117

(0.129)

Dummy Oct 2005 x Government ownership

0.064

$(0.137)$

Dummy Nov 2005 x Government ownership

$(0.133)$

Dummy Dec 2005 x Government ownership

0.057

$(0.126)$

Dummy Jan 2006 x Government ownership

$(0.132)$

Dummy Feb 2006 x Government ownership

0.056

$(0.130)$

Dummy Mar 2006 x Government ownership

0.065

(0.130)

Dummy Apr 2006 x Government ownership

$(0.131)$

0.066

Dummy May 2006 x Government ownership

$(0.131)$

Dummy Jun 2006 x Government ownership

$(0.120)$

0.050

(0.119)

0.046

Dummy Aug 2006 x Government ownership

(0.119)

0.088

Dummy Sep 2006 x Government ownership

(0.119)

0.096

$(0.123)$

0.091

(0.125)

0.106

(0.128)

0.115

(0.137)

0.109

(0.144)

0.107

(0.140)

0.121

(0.147) 
Dummy May 2007 x Government ownership

(0.146)

Dummy Jun 2007 x Government ownership

0.152

$(0.135)$

Dummy Jul 2007 x Government ownership

(0.130)

0.138

Dummy Aug 2007 x Government ownership

(0.120)

Dummy Sep 2007 x Government ownership

0.143

(0.111)

Dummy Oct 2007 x Government ownership

0.172

(0.107)

Dummy Nov 2007 x Government ownership

0.108

(0.097)

Dummy Dec 2007 x Government ownership

0.066

$(0.091)$

Dummy Jan 2008 x Government ownership

0.051

$(0.083)$

Dummy Feb 2008 x Government ownership

0.014

(0.080)

Dummy Mar 2008 x Government ownership

$(0.075)$

Dummy Apr 2008 x Government ownership $-0.027$

$(0.073)$

Dummy May 2008 x Government ownership $-0.047$

$(0.081)$

$-0.152$

$(0.126)$

Dummy Jul 2008 x Government ownership

Dummy Aug 2008 x Government ownership

$(0.079)$

$-0.096$

$(0.062)$

$-0.062$

$(0.043)$

0.018

(0.139)

Dummy Jan 2004 x Government directors

(0.155)

0.040

(0.147)

0.039

(0.155)

0.043

(0.149) 
Dummy May 2004 x Government directors

$(0.123)$

Dummy Jun 2004 x Government directors

0.055

(0.116)

Dummy Jul 2004 x Government directors

(0.116)

Dummy Aug 2004 x Government directors

(0.112)

Dummy Sep 2004 x Government directors

0.068

$(0.121)$

Dummy Oct 2004 x Government directors

(0.129)

Dummy Nov 2004 x Government directors

$(0.131)$

Dummy Dec 2004 x Government directors

Dummy Jan 2005 x Government directors

$(0.133)$

Dummy Feb 2005 x Government directors

Dummy Mar 2005 x Government directors

Dummy Apr 2005 x Government directors

Dummy May 2005 x Government directors

Dummy Jun 2005 x Government directors

Dummy Jul 2005 x Government directors

Dummy Aug 2005 x Government directors

Dummy Sep 2005 x Government directors

Dummy Oct 2005 x Government directors

Dummy Nov 2005 x Government directors

Dummy Dec 2005 x Government directors

Dummy Jan 2006 x Government directors

Dummy Feb 2006 x Government directors

Dummy Mar 2006 x Government directors 
Dummy Apr 2006 x Government directors

Dummy May 2006 x Government directors

Dummy Jun 2006 x Government directors

$(0.123)$

0.071

(0.116)

Dummy Jul 2006 x Government directors

Dummy Aug 2006 x Government directors

Dummy Sep 2006 x Government directors

Dummy Oct 2006 x Government directors

$(0.115)$

0.063

$(0.122)$

Dummy Nov 2006 x Government directors

Dummy Dec 2006 x Government directors

Dummy Jan 2007 x Government directors

Dummy Feb 2007 x Government directors

Dummy Mar 2007 x Government directors

Dummy Apr 2007 x Government directors

Dummy May 2007 x Government directors

0.155

$(0.159)$

Dummy Jun 2007 x Government directors

0.168

(0.146)

Dummy Jul 2007 x Government directors

0.138

(0.139)

Dummy Aug 2007 x Government directors

0.133

(0.124)

0.148

(0.117)

0.095

(0.112)

0.106

Dummy Nov 2007 x Government directors

0.135

(0.087)

Dummy Jan 2008 x Government directors

0.125

(0.078)

Dummy Feb 2008 x Government directors 
Dummy Aug 2008 x Government directors

Notes: Standard errors clustered at the firm level are shown in parentheses. All regressions include firm fixed effects. Column (2) includes also month fixed effects. Prices stands for a firm's monthly stock price scaled by its value in December 2007, Government ownership is a dummy equal to 1 if the government acquired a positive shareholding in the firm at nationalization, and Government directors is a dummy equal to 1 if the government acquired the right to appoint at least one director to the board of the firm at nationalization. *** Significant at the $1 \%$ level. 


\begin{tabular}{|c|c|c|}
\hline & $\begin{array}{c}(1) \\
\text { Prices }\end{array}$ & $\begin{array}{c}(2) \\
\text { Prices } \\
\end{array}$ \\
\hline Post Apr $2006 *$ Government ownership & $\begin{array}{l}-0.062 \\
(0.079)\end{array}$ & \\
\hline Post Apr 2006 * Government ownership & $\begin{array}{c}0.028 \\
(0.080)\end{array}$ & \\
\hline Post Dec 2007 * Government ownership & & $\begin{array}{l}-0.154 \\
(0.098)\end{array}$ \\
\hline Post Dec $2007 *$ Government directors & & $\begin{array}{c}0.021 \\
(0.101)\end{array}$ \\
\hline Sample & $\begin{array}{c}\text { Dec } 2003-\text { Nov } \\
2008\end{array}$ & $\begin{array}{c}\text { Dec } 2003-\text { Nov } \\
2008\end{array}$ \\
\hline Observations & 3,481 & 3,481 \\
\hline \multicolumn{3}{|c|}{$\begin{array}{l}\text { Notes: Standard errors clustered at the firm level are shown in parentheses. The } \\
\text { regression includes firm fixed effects and month fixed effects. Prices stands for a } \\
\text { firm's monthly stock price scaled by its value in December } 2007 \text {, Government } \\
\text { ownership is a dummy equal to } 1 \text { if the government acquired a positive } \\
\text { shareholding in the firm at nationalization, Government directors is a dummy } \\
\text { equal to } 1 \text { if the government acquired the right to appoint at least one director to } \\
\text { the board of the firm at nationalization, Post Apr } 2006 \text { is a dummy variable equal } \\
\text { to } 1 \text { from April } 2006 \text { on, and Post Dec } 2007 \text { is a dummy variable equal to } 1 \text { from } \\
\text { December } 2007 \text { on. }\end{array}$} \\
\hline
\end{tabular}

